\title{
Artemyrianins A-G from Artemisia myriantha and Their Cytotoxicity Against HepG2 Cells
}

\author{
Shuang Tang ${ }^{1,2} \cdot$ Yun-Bao Ma ${ }^{1} \cdot$ Chang-An Geng ${ }^{1} \cdot$ Cheng Shen ${ }^{1,2} \cdot$ Tian-Ze Li $^{1} \cdot$ Xue-Mei Zhang ${ }^{1} \cdot$ Li-Hua Su $^{1,2}$. \\ Zhen $\mathrm{Gao}^{1,2}$. Jing Hu${ }^{1} \cdot$ Ji-Jun Chen ${ }^{1,2}$ (I)
}

Received: 27 April 2020 / Accepted: 17 June 2020 / Published online: 28 June 2020

(c) The Author(s) 2020

\begin{abstract}
Four new sesquiterpenoids, artemyrianins A-D (1-4), and three new norlignans, artemyrianins E-G (5-7), together with five known compounds (8-12), were isolated from the aerial parts of Artemisia myriantha (Asteraceae). The new compounds were established by spectroscopic data analyses (HRMS, IR, 1D and 2D NMR), and their absolute configurations were confirmed by the single-crystal X-ray diffraction or ECD calculations. The isolates showed cytotoxicity against $\mathrm{HepG} 2$ cells with $\mathrm{IC}_{50}$ values ranging from 33.3 to $145.2 \mu \mathrm{M}$.
\end{abstract}

\section{Graphic Abstract}
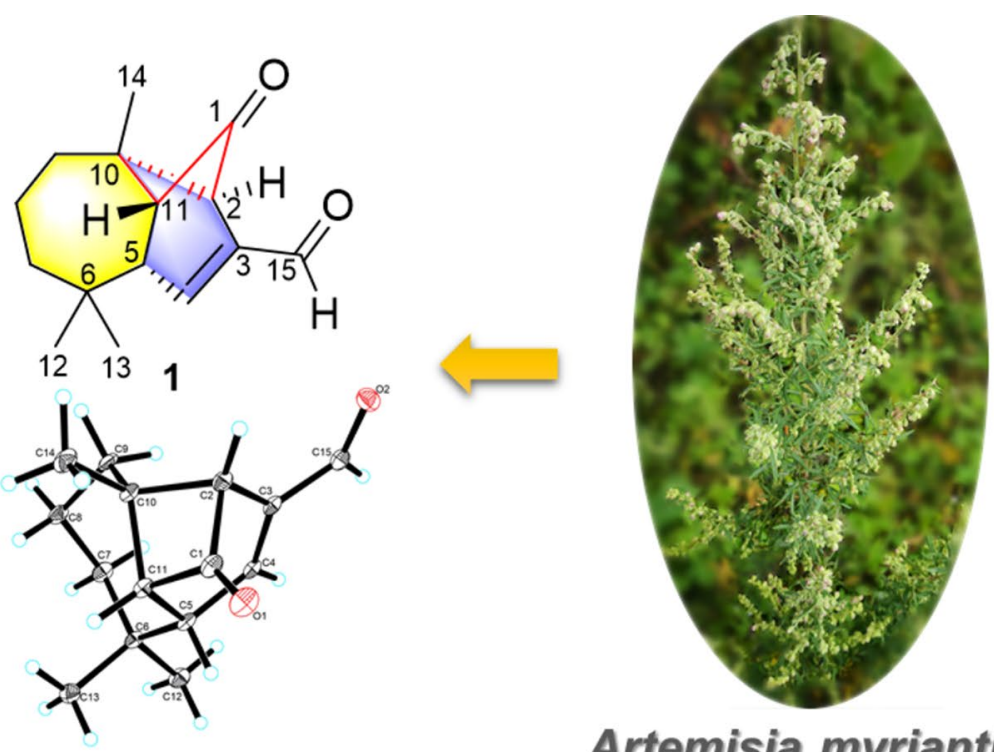<smiles>OC[C@H](/C=C/c1ccc2c(c1)OCO2)Cc1ccc2c(c1)OCO2</smiles>

$\mathrm{IC}_{50}(\mathrm{HepG})$

$33.3 \mu \mathrm{M}$

Keywords Artemisia myriantha $\cdot$ Artemyrianins A-G $\cdot$ Sesquiterpenoids $\cdot$ Norlignans $\cdot$ Cytotoxicity $\cdot$ HepG2 cells

Electronic supplementary material The online version of this article (https://doi.org/10.1007/s13659-020-00255-z) contains supplementary material, which is available to authorized users.

Ji-Jun Chen

chenjj@mail.kib.ac.cn

Extended author information available on the last page of the article

\section{Introduction}

Hepatocellular carcinoma (HCC) resulting in 780000 deaths every year is the fourth cause of cancer mortality [1]. The treatment for advanced HCC has long been unsatisfied until the authorization of sorafenib in 2007. Afterwards, six drugs involving nivolumab, regorafenib, lenvatinib, 
pembrolizumab, ramucirumab and cabozantinib have been approved by the Food and Drug Administration (FDA). Whereas, the drug resistance and side effects are inevitable [2]. Natural products, especially sesquiterpenoids, such as artemisinin, thapsigargin, parthenolide [3] and arglabin [4] are leading compounds for the development of potent therapeutic agents for neoplastic diseases, which inspired us to search for anti-HCC active compounds with high efficiency and low toxicity from natural sources.

Artemisia myriantha Wall. ex Bess., a folk medicine herb, has been used to treat inflammation and menorrhagia diseases [5]. According to previous investigation, sesquiterpenoids [5-9], dimeric sesquiterpenoids [5], flavones [7] and volatile oils [10-12] with antibacterial, anticancer and immunomodulating activity have been reported from this plant. In order to investigate the bioactive constituents of $A$. myriantha, our phytochemical study led to the isolation of four new sesquiterpenoids, artemyrianins A-D (1-4), three new norlignans, artemyrianins E-G (5-7), as well as five known compounds (Fig. 1). Herein, we reported their isolation, structural identification and cytotoxicity on HepG2 cells.

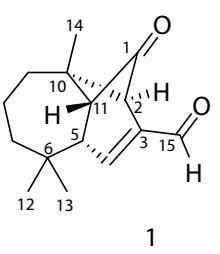

1<smiles>OC[C@H](/C=C/c1ccc2c(c1)OCO2)Cc1ccc2c(c1)OCO2</smiles>

5<smiles>O=C1OC[C@H](C(=O)c2ccc3c(c2)OCO3)[C@H]1Cc1ccc2c(c1)OCO2</smiles>

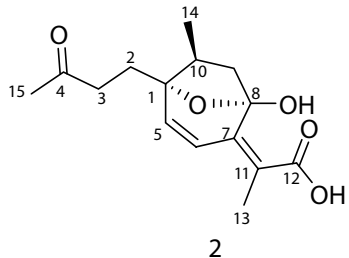

2<smiles>OC[C@H](/C=C\c1ccc2c(c1)OCO2)Cc1ccc2c(c1)OCO2</smiles>

6<smiles>COc1cc2ccc(=O)oc2c(OC)c1O</smiles>

10

\section{Results and Discussion}

Artemyrianin A (1) was obtained as colorless prismatic crystals and had a molecular formula of $\mathrm{C}_{15} \mathrm{H}_{20} \mathrm{O}_{2}$ with six indices of hydrogen deficiency from the (+)-HRESIMS $(\mathrm{m} / \mathrm{z}$ 233.1518 $[\mathrm{M}+\mathrm{H}]^{+}$, calcd for 233.1536). The IR spectrum indicated the presence of carbonyl (1771 and $1671 \mathrm{~cm}^{-1}$ ) and double bond $\left(1606 \mathrm{~cm}^{-1}\right)$ functionalities. The ${ }^{1} \mathrm{H}$ NMR data (Table 1) exhibited signals for three singlet methyls at $\delta_{\mathrm{H}} 1.28\left(\mathrm{H}_{3}-14\right), 1.16\left(\mathrm{H}_{3}-13\right)$ and $1.01\left(\mathrm{H}_{3}-12\right)$, a double bond at $\delta_{\mathrm{H}} 7.00(1 \mathrm{H}, \mathrm{d}, J=2.2 \mathrm{~Hz}, \mathrm{H}-4)$ and a formyl group at $\delta_{\mathrm{H}} 9.54(1 \mathrm{H}, \mathrm{s}, \mathrm{H}-15)$. The ${ }^{13} \mathrm{C}$ NMR (DEPT) spectrum displayed 15 carbon resonances, including three methyls at $\delta_{\mathrm{C}} 30.5(\mathrm{C}-13), 27.5(\mathrm{C}-14)$ and $26.5(\mathrm{C}-12)$, three methylenes at $\delta_{\mathrm{C}} 43.2(\mathrm{C}-7), 33.8(\mathrm{C}-9)$ and $21.6(\mathrm{C}-8)$, four methines [including an olefinic at $\delta_{\mathrm{C}} 148.7(\mathrm{C}-4)$ ], three quaternary carbons [including an olefinic at $\delta_{\mathrm{C}} 145.5$ (C-3)], a formyl group at $\delta_{\mathrm{C}} 189.9$ (C-15) and a keto carbonyl at $\delta_{\mathrm{C}} 203.9$ (C-1). Inspection of its ${ }^{1} \mathrm{H}$ and ${ }^{13} \mathrm{C}$ NMR (DEPT) data suggested the similar structure with vulgarone $\mathrm{A}$ [13] except that a methyl $\left(\delta_{\mathrm{H}} 1.78, \delta_{\mathrm{C}} 23.5\right)$ in vulgarone $\mathrm{A}$ was replaced by a formyl group $\left(\delta_{\mathrm{H}} 9.54, \delta_{\mathrm{C}} 189.9\right)$ in 1 . The<smiles>C=C(C(C)=O)[C@H]1C[C@H]2[C@H](O)CCC[C@]2(C)C[C@H]1O</smiles><smiles>O=C1OC[C@H](Cc2ccc3c(c2)OCO3)[C@H]1Cc1ccc2c(c1)OCO2</smiles>

7<smiles>O[C@@H]1[C@H](c2ccc3c(c2)OCO3)OC[C@H]1Cc1ccc2c(c1)OCO2</smiles><smiles>CC(=O)c1cc2cc(C(C)(C)O)oc2cc1O</smiles>

12<smiles>COc1cc2ccc(=O)oc2c2c1OCO2</smiles>

11

Fig. 1 Chemical structures of compounds 1-12 
HMBC correlations (Fig. 2) from H-15 to C-2 ( $\left.\delta_{\mathrm{C}} 61.2\right), \mathrm{C}-3$ and $\mathrm{C}-4$ confirmed the position of the formyl group at $\mathrm{C}-3$. The single-crystal X-ray diffraction experiment using $\mathrm{Cu} K \alpha$ radiation (Fig. 3) unambiguously determined its structure as $3 E-(2 R, 5 S, 10 S, 11 R)-15$-oxovulgarone $\mathrm{A}$.

Artemyrianin $\mathrm{B}$ (2) was purified as a white amorphous powder with a molecular formula of $\mathrm{C}_{15} \mathrm{H}_{20} \mathrm{O}_{5}$ by the $[\mathrm{M}-\mathrm{H}]^{-}$ion at $\mathrm{m} / \mathrm{z} 279.1242$ (calcd for 279.1238) in the (-)-HRESIMS, exhibiting six degrees of unsaturation. The absorption bands at $3435,1771,1716$ and $1633 \mathrm{~cm}^{-1}$ in the IR spectrum explained the existence of hydroxy, carbonyl and double bond groups. Two olefinic protons at $\delta_{\mathrm{H}} 6.59$ (d, $J=9.5 \mathrm{~Hz}, \mathrm{H}-6)$ and $6.19(\mathrm{~d}, J=9.5 \mathrm{~Hz}, \mathrm{H}-5)$, along with three methyls at $\delta_{\mathrm{H}} 2.15\left(\mathrm{~s}, \mathrm{H}_{3}-15\right), 1.89\left(\mathrm{~s}, \mathrm{H}_{3}-13\right)$ and $1.01\left(\mathrm{~d}, J=7.0 \mathrm{~Hz}, \mathrm{H}_{3}-14\right)$ were recognized in the ${ }^{1} \mathrm{H}$ NMR data. The ${ }^{13} \mathrm{C}$ NMR (DEPT) data showed 15 resonances ascribed to three methyls at $\delta_{\mathrm{C}} 30.0(\mathrm{C}-15), 15.5$ $(\mathrm{C}-14)$ and 8.2 (C-13), three methylenes at $\delta_{\mathrm{C}} 38.7$ (C-9), $38.1(\mathrm{C}-3)$ and 28.9 (C-2), three methines [including two olefinic at $\delta_{\mathrm{C}} 142.6(\mathrm{C}-5)$ and $119.5(\mathrm{C}-6)$ ], an oxygenated tertiary carbon at $\delta_{\mathrm{C}} 87.2(\mathrm{C}-1)$, a dioxygenated secondary carbon at $\delta_{\mathrm{C}} 106.4$ (C-8), two olefinic quaternary carbons at $\delta_{\mathrm{C}} 155.7(\mathrm{C}-7)$ and $117.2(\mathrm{C}-11)$, and two carbonyls at $\delta_{\mathrm{C}} 207.8(\mathrm{C}-4)$ and $172.0(\mathrm{C}-12)$, indicating a sesquiterpenoid scaffold. The spin systems of $\mathrm{H}_{2}-2 / \mathrm{H}_{2}-3, \mathrm{H}-5 / \mathrm{H}-6$ and
$\mathrm{H}_{2}-9 / \mathrm{H}-10 / \mathrm{H}_{3}-14$ inferred from the ${ }^{1} \mathrm{H}-{ }^{1} \mathrm{H}$ COSY spectrum, together with the $\mathrm{HMBC}$ correlations from $\mathrm{H}_{3}-15$ to $\mathrm{C}-3$ and C-4, from $\mathrm{H}_{3}-13$ to C-7, C-11 and C-12, from $\mathrm{H}-6$ to $\mathrm{C}-7$ and $\mathrm{C}-8$, from $\mathrm{H}_{2}-9\left(\delta_{\mathrm{H}} 2.60,1.63\right)$ to $\mathrm{C}-8$, and from $\mathrm{H}_{2}-2\left(\delta_{\mathrm{H}}\right.$ $2.24,1.94)$ to $\mathrm{C}-1, \mathrm{C}-5$ and $\mathrm{C}-10\left(\delta_{\mathrm{C}} 41.7\right)$ constructed its planar structure with a 7 -membered ring. An oxygen bridge linking $\mathrm{C}-1$ and $\mathrm{C}-8$ was affirmed by the de-shielded shifts of C-1 $\left(\delta_{\mathrm{C}} 87.2\right)$ and C-8 $\left(\delta_{\mathrm{C}} 106.4\right)$, and thus fulfilled the unsaturation degrees. The small coupling constant between H-5 and H-6 $(J=9.5 \mathrm{~Hz})$ indicated the cis-configuration of $\Delta^{5}$. The cis-configuration of $\Delta^{7(11)}$ was deduced with the fact that the cross-peak between $\mathrm{H}-6$ and $\mathrm{H}_{3}-13$ was observed in the ROESY spectrum. In addition, the ROESY correlations (Fig. 4) of $\mathrm{H}_{2}-2\left(\delta_{\mathrm{H}} 2.24,1.94\right)$ with $\mathrm{H}_{3}-14\left(\delta_{\mathrm{H}} 1.01\right)$ revealed their homolateral orientation. Its absolute configuration was established by the electronic circular dichroism (ECD) experiment which fitted well with the calculated ECD curve (Fig. 5). Therefore, compound $\mathbf{2}$ was characterized as $5 Z, 7(11) Z-(1 R, 8 S, 10 S)$-1,8-epoxy-8-hydroxy-4,5-secoguaian-5,7(11)-dien-12-oic acid.

Artemyrianin $\mathrm{C}(3)$ was assigned a molecular formula of $\mathrm{C}_{18} \mathrm{H}_{26} \mathrm{O}_{5}$ by the analysis of the (+)-HRESIMS $(\mathrm{m} / \mathrm{z}$ $345.1675[\mathrm{M}+\mathrm{Na}]^{+}$, calcd for 345.1672), with six double bond equivalents. The characteristic absorption bands at 3434 (hydroxy), 1735 and 1720 (carbonyl) and $1629 \mathrm{~cm}^{-1}$
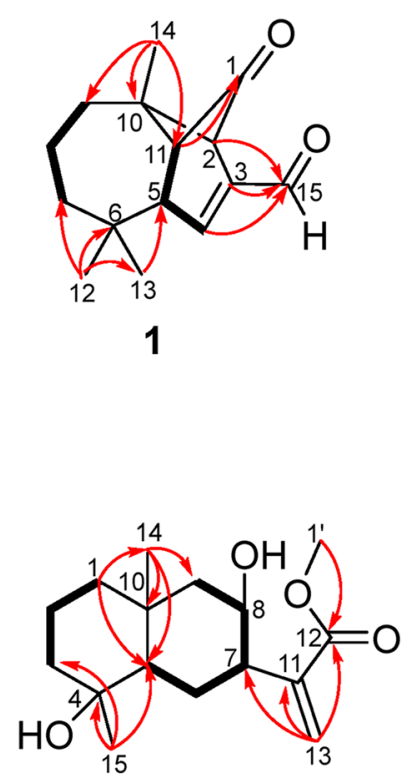

4

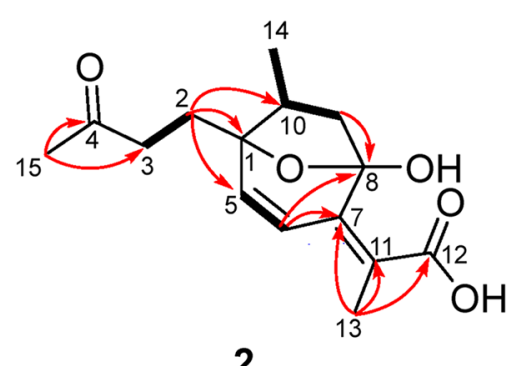

2

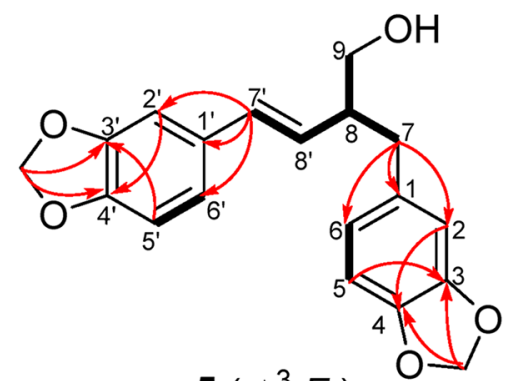

$5\left(\Delta^{3} E\right)$

$6\left(\Delta^{3} Z\right)$
7
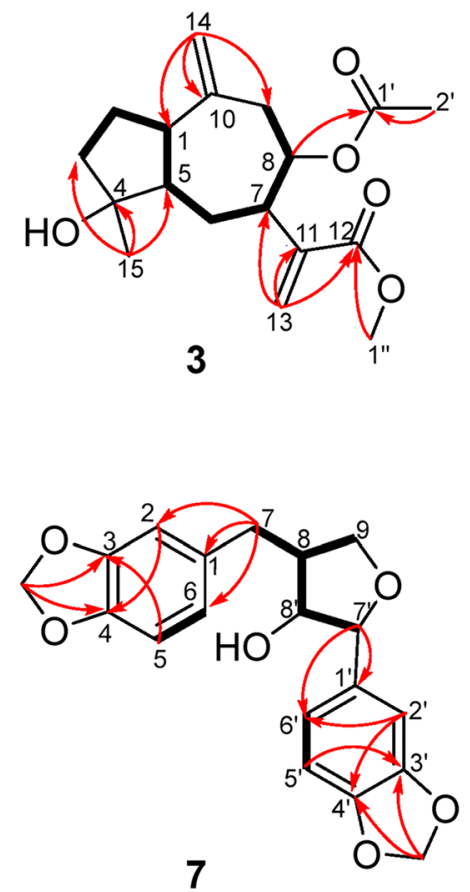

3

\section{${ }^{1} \mathrm{H}-{ }^{1} \mathrm{HCOSY}-\mathrm{HMBC}$}

Fig. 2 Key ${ }^{1} \mathrm{H}-{ }^{1} \mathrm{H}$ COSY and HMBC correlations of compounds 1-7 


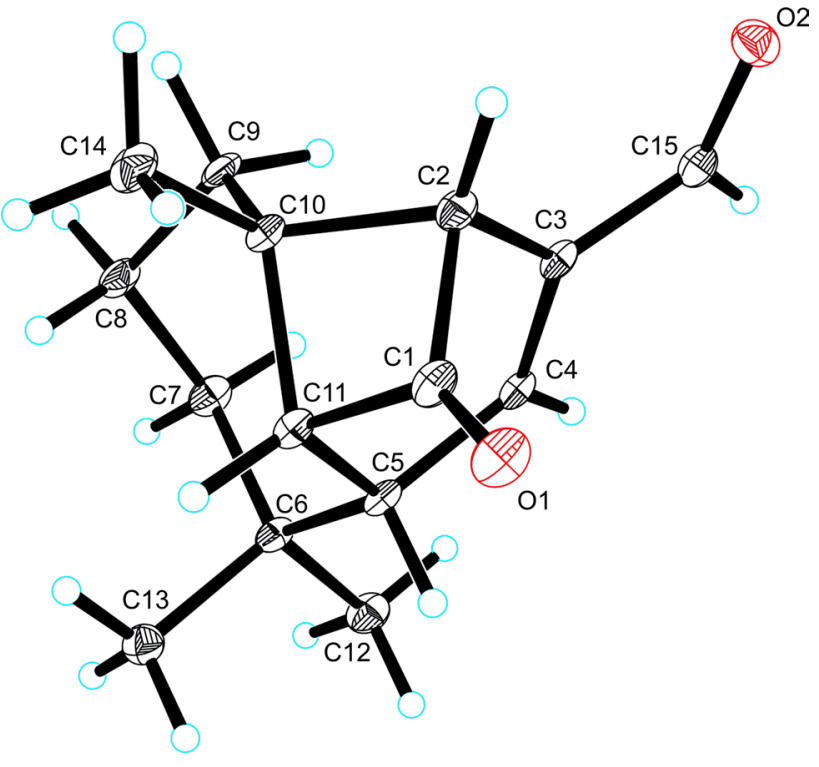

Fig. 3 The X-ray ORTEP drawing of compound $\mathbf{1}$

(double bond) were recognized in the IR spectrum. Compared with $2 \alpha$-acetoxy- $4 \alpha$-hydroxy-1 $\beta$-guai-11(13),10(14)dien-12,8 $\alpha$-olide [14], the acetoxy group at C-2 was absent and the $\alpha$-methylene- $\gamma$-lactone ring was opened in $\mathbf{3}$, which connected to a methoxy $\left[\delta_{\mathrm{H}} 3.76\left(\mathrm{~s}, \mathrm{H}_{3}-1^{\prime \prime}\right)\right.$ and $\delta_{\mathrm{C}} 52.2$ $\left.\left(\mathrm{C}-1^{\prime \prime}\right)\right]$ and an extra acetyl group $\left[\delta_{\mathrm{H}} 1.98\left(\mathrm{~s}, \mathrm{H}_{3}-2^{\prime}\right)\right.$ and $\left.\delta_{\mathrm{C}} 170.6\left(\mathrm{C}-1^{\prime}\right), 21.3\left(\mathrm{C}-2^{\prime}\right)\right]$. The HMBC correlations from $\mathrm{H}-8\left(\delta_{\mathrm{H}} 5.09\right)$ to $\mathrm{C}-1$ ', and from $\mathrm{H}_{3}-1$ " to $\mathrm{C}-12\left(\delta_{\mathrm{C}} 167.3\right)$ verified the acetyl group at $\mathrm{C}-8$ and the presence of methyl ester in the structure. Moreover, the shielded shift of C-2 from $\delta_{\mathrm{C}} 75.6(\mathrm{CH})$ in $2 \alpha$-acetoxy- $4 \alpha$-hydroxy- $1 \beta$-guai11(13),10(14)-dien-12,8 $\alpha$-olide to $\delta_{\mathrm{C}} 27.0\left(\mathrm{CH}_{2}\right)$ in 3 interpreted the absence of the acetoxy group in 3 . In the ROESY experiment, the correlations of $\mathrm{H}-5$ with $\mathrm{H}-1, \mathrm{H}-7$ and $\mathrm{H}_{3}-15$, and of $\mathrm{H}-7$ with $\mathrm{H}-8$ explained their same orientation. Its absolute configuration was proposed as $1 R, 4 S, 5 R, 7 R, 8 R$ by means of ECD calculation. Consequently, compound $\mathbf{3}$ was defined as $(1 R, 4 S, 5 R, 7 R, 8 R)$-4-hydroxy-8-acetoxyguaian-10(14),11(13)-dien-12-oic acid methyl ester.

Artemyrianin D (4) was proposed a molecular formula of $\mathrm{C}_{16} \mathrm{H}_{26} \mathrm{O}_{4}$ based on the (+)-HRESIMS ( $\mathrm{m} / z, 305.1725$ $[\mathrm{M}+\mathrm{Na}]^{+}$, calcd for 305.1723$)$. The IR spectrum suggested absorption bands for hydroxy, carbonyl and double bond functionalities at 3501, 3459, 1701 and $1626 \mathrm{~cm}^{-1}$. Its ${ }^{1} \mathrm{H}$ and ${ }^{13} \mathrm{C}$ NMR (DEPT) data exhibited similarity with those of 8-desacyl-4 $\beta$-hydroxy-15-dihydrocarmanin [15] except for the absence of three hydroxyl groups in $\mathbf{4}$, which was proved by the shielded shifts of $\mathrm{C}-1$ [from $\delta_{\mathrm{C}} 76.1(\mathrm{CH})$ to $\delta_{\mathrm{C}}$ $41.3\left(\mathrm{CH}_{2}\right)$ ], C-6 [from $\delta_{\mathrm{C}} 66.3(\mathrm{CH})$ to $\delta_{\mathrm{C}} 20.1\left(\mathrm{CH}_{2}\right)$ ] and C-15 [from $\delta_{\mathrm{C}} 63.7\left(\mathrm{CH}_{2}\right)$ to $\delta_{\mathrm{C}} 23.0\left(\mathrm{CH}_{3}\right)$ ], respectively. The above deduction was further supported by the HMBC correlations of $\mathrm{H}_{2}-1\left(\delta_{\mathrm{H}} 1.45,1.08\right)$ with $\mathrm{C}-3\left(\delta_{\mathrm{C}} 43.6\right)$, C-5
$\left(\delta_{\mathrm{C}} 56.0\right)$ and $\mathrm{C}-14\left(\delta_{\mathrm{C}} 21.1\right)$, of $\mathrm{H}_{2}-6\left(\delta_{\mathrm{H}} 1.69\right)$ with $\mathrm{C}-8\left(\delta_{\mathrm{C}}\right.$ $68.0), \mathrm{C}-10\left(\delta_{\mathrm{C}} 34.8\right)$ and $\mathrm{C}-11\left(\delta_{\mathrm{C}} 142.0\right)$, and of $\mathrm{H}_{3}-15\left(\delta_{\mathrm{H}}\right.$ $1.20)$ with $\mathrm{C}-3, \mathrm{C}-4\left(\delta_{\mathrm{C}} 72.4\right)$ and $\mathrm{C}-5$. The ROESY correlations of $\mathrm{H}-7$ with $\mathrm{H}-5, \mathrm{H}-8$ and $\mathrm{H}-9 \mathrm{~b}$, and of $\mathrm{H}_{3}-14$ with $\mathrm{H}-9 \mathrm{a}$ and $\mathrm{H}_{3}-15$ suggested that $\mathrm{H}-5, \mathrm{H}-7$ and $\mathrm{H}-8$ were on the same side, while the $\mathrm{H}_{3}-14$ and $\mathrm{H}_{3}-15$ were on the other side. The absolute configuration of $\mathbf{4}$ was constructed from the high match of experimental and calculated ECD data. Thus, compound 4 was identified as $(4 R, 5 R, 7 R, 8 R, 10 R)$ 4,8-dihydroxyeudesma-11(13)-en-12-oic acid methyl ester.

Artemyrianin E (5) was isolated as a yellowish oil and had a chemical composition of $\mathrm{C}_{19} \mathrm{H}_{18} \mathrm{O}_{5}$ with eleven degrees of unsaturation from the HREIMS $(\mathrm{m} / \mathrm{z} 326.1148$ $[\mathrm{M}]^{+}$, calcd for 326.1154). The IR spectrum displayed the existence of hydroxy $\left(3384 \mathrm{~cm}^{-1}\right)$ and phenyl ring (1606, 1503 and $1444 \mathrm{~cm}^{-1}$ ) groups. The similar ${ }^{1} \mathrm{H}$ and ${ }^{13} \mathrm{C}$ NMR (DEPT) data (Table 2) of 5 to those of (+)-artemisarin [16] revealed their closely related structures. The large coupling constant of $\mathrm{H}-7^{\prime}$ with $\mathrm{H}-8^{\prime}\left(J_{7^{\prime}, 8^{\prime}}=15.7 \mathrm{~Hz}\right)$ indicated the $E$-configuration of $\Delta^{7^{\prime}}$ in $\mathbf{5}$, instead of $Z$-configuration in $(+)$-artemisarin $\left(J_{7^{\prime}, 8^{\prime}}=11.2 \mathrm{~Hz}\right)$. The absolute stereochemistry of $\mathbf{5}$ was elucidated by the high agreement between the experimental and calculated ECD spectra. Hence, compound 5 was assigned as $7^{\prime} E-(8 S)$-artemisarin.

Artemyrianin F (6) gave a molecular formula of $\mathrm{C}_{19} \mathrm{H}_{18} \mathrm{O}_{5}$ from the HREIMS at $\mathrm{m} / z 326.1152\left([\mathrm{M}]^{+}\right.$, calcd for 326.1154). Its IR spectrum presented the characteristic absorption bands of hydroxy $\left(3404 \mathrm{~cm}^{-1}\right)$ and phenyl ring $\left(1607,1503\right.$ and $\left.1442 \mathrm{~cm}^{-1}\right)$ functionalities. The high resemblance between the ${ }^{1} \mathrm{H}$ and ${ }^{13} \mathrm{C}$ NMR (DEPT) data of 6 and (+)-artemisarin [16] manifested their same planar structure. The geometry of $\Delta^{7^{\prime}}$ was $Z$-form as deduced from the small $J_{7^{\prime}, 8^{\prime}}$ value of $11.6 \mathrm{~Hz}$. The ECD spectrum of 6 was superimposable to the calculated one, compound 6 was thus elucidated as $7{ }^{\prime} Z-(8 R)$-artemisarin.

Artemyrianin G (7) had a molecular formula of $\mathrm{C}_{19} \mathrm{H}_{18} \mathrm{O}_{6}$ based on the HREIMS at $\mathrm{m} / z$ 342.1104 ([M] ${ }^{+}$, calcd for 342.1103). The existence of hydroxy $\left(3406 \mathrm{~cm}^{-1}\right)$ and phenyl ring $\left(1608,1503\right.$ and $\left.1443 \mathrm{~cm}^{-1}\right)$ groups was recognized in the IR spectrum. Its ${ }^{1} \mathrm{H}$ and ${ }^{13} \mathrm{C}$ NMR (DEPT) spectroscopic data were close to those of mandshuricol A [17], but the main difference was that C-8' in 7 was a methine attached to a hydroxy with chemical shift of $\delta_{\mathrm{C}} 79.6$ and $\mathrm{C}-8^{\prime}$ in mandshuricol A was a quaternary carbon attached to a hydroxy and a hydroxymethyl group with chemical shift of $\delta_{\mathrm{C}} 83.4$, which suggested that 7 was de-hydroxymethyl derivative at $\mathrm{C}-\mathrm{8}^{\prime}$ of mandshuricol A. The above deduction was supported by the ${ }^{1} \mathrm{H}-{ }^{1} \mathrm{H}$ COSY correlations of $\mathrm{H}_{2}-9 / \mathrm{H}-8 / \mathrm{H}-8^{\prime} / \mathrm{H}-7^{\prime}$. The ROESY correlations of $\mathrm{H}-8 / \mathrm{H}-8^{\prime}, \mathrm{H}-7^{\prime} / \mathrm{H}-8^{\prime}$ and $\mathrm{H}-8 / \mathrm{H}-7^{\prime}$ suggested the same orientation of $\mathrm{H}-8, \mathrm{H}-7^{\prime}$ and $\mathrm{H}-8^{\prime}$. Its absolute configuration was proposed owning to the well match between the experimental and calculated ECD curves. 
Accordingly, compound 7 was established as $\left(8 R, 7^{\prime} R, 8^{\prime} R\right)$ 8'-dehydroxymethylmandshuricol A.

By comparing their ${ }^{1} \mathrm{H}$ and ${ }^{13} \mathrm{C}$ NMR (DEPT) spectroscopic data with those reported in literatures, five known compounds were identified as (-)-hinokinin (8) [18], $\left(8 R, 8^{\prime} R\right)-4,4^{\prime}, 5,5^{\prime}$-bis(methylenedioxy)-7'-oxolignano-9, $9^{\prime}$ lactone (9) [19], isofraxidin (10) [20], dracunculin (11) [21] and 5-acetyl-6-hydroxy-2-(1-hydroxy-1-methylethyl)benzofuran (12) [22], respectively.

In addition to four sesquiterpenoids (1-4), five lignans (5-9), two coumarins (10 and 11) and a benzofuran (12) were isolated from A. myriantha for the first time. The isolates were assayed for their cytotoxicity against HepG2 cells with sorafenib as the positive control. As a result (Table 3), all compounds showed cytotoxic activity with $\mathrm{IC}_{50}$ values ranging from 33.3 to $145.2 \mu \mathrm{M}$.

\section{Experimental}

\subsection{General Experimental Procedures}

HRESIMS data were obtained from an LCMS-IT-TOF mass spectrometer (Shimadzu, Kyoto, Japan) or a UPLC/ Q-TOF mass spectrometer (Agilent Technologies, Santa Clara, USA). HREIMS data were acquired on an Agilent G6230 mass spectrometer (Agilent Technologies, Santa Clara, USA). 1D and 2D NMR spectra were recorded on Avance III HD 400 (Bruker, Bremerhaven, Germany) or III 600 (Bruker, Fällanden, Switzerland) spectrometers with TMS as the internal standard. IR spectra were performed on a NICOLET iS10 spectrometer (Thermo Fisher Scientific, Madison, USA) with KBr pellets or ATR ITXDIAMOND mode. UV spectra were measured on a Shimadzu UV-2700 spectrophotometer (Shimadzu, Suzhou, China). X-ray crystallographic data with $\mathrm{Cu} K \alpha$ radiation were collected on a Bruker D8 QUEST apparatus (Bruker, Karlsruher, Germany). ECD experiments were conducted with an Applied Photophysics Chirascan instrument (Applied Photophysics, Surrey, UK). Optical rotations were obtained on an Autopol VI automatic polarimeter (Rudolph Research Analytical, Hackettstown, NJ, USA). Melting point was acquired on an $\mathrm{SGW}^{\circledR} \mathrm{X}-4 \mathrm{~B}$ microscopic melting point instrument (Shanghai Precision and Scientific Instrument Co., Ltd., Shanghai, China). Silica gel (200-300 mesh) and Sephadex LH-20 gel (20-50 $\mu \mathrm{m})$ for column chromatography were purchased from Linyi Haixiang Co., Ltd. (Haixiang, Linyi, China) and Pharmacia Fine Chemical Co., Ltd., (Pharmacia, Uppsala, Sweden), respectively. TLC detection was carried out using silica gel HSGF254 plates (Jiangyou, Chemical Co., Ltd., Yantai, China), and compounds were visualized by heating after spraying with $10 \% \mathrm{H}_{2} \mathrm{SO}_{4}$ in $\mathrm{EtOH}(\mathrm{v} / \mathrm{v})$.
MPLC separation was achieved on a Dr-Flash II instrument (Lisure Science Co., Ltd., Suzhou, China) with an MCI gel CHP 20P column (75-150 $\mu \mathrm{m}$, Mitsubishi Chemical Corporation, Tokyo, Japan). Semi-preparative HPLC purification was performed on a Shimadzu HPLC system equipped with LC-20AR pumps and a model SPD-M20A UV detector (Shimadzu, Kyoto, Japan) using an Agilent Eclipse XDB-C ${ }_{18}$ column $(5 \mu \mathrm{m}, 9.4 \times 250 \mathrm{~mm}$, Agilent Technologies, Santa Clara, USA).

\subsection{Plant Material}

The aerial parts of $A$. myriantha Wall. ex Bess. were obtained from Lijiang, Yunnan Province, China, in September 2018, and identified by Dr. Zhuo Zhou (Key Laboratory for Plant Diversity and Biogeography of East Asia, Kunming Institute of Botany, Chinese Academy of Sciences). A voucher specimen (No. 201809AM) was stored in the Laboratory of Antivirus and Natural Medicinal Chemistry, Kunming Institute of Botany, Chinese Academy of Sciences.

\subsection{Extraction and Isolation}

The air-dried aerial parts of A. myriantha $(24.7 \mathrm{~kg})$ were smashed and extracted with $90 \% \mathrm{EtOH}$ for two times at room temperature (each $100 \mathrm{~L}$, four days). The combined extracts were concentrated and suspended in $\mathrm{H}_{2} \mathrm{O}$, which was extracted with EtOAc. The EtOAc portion $(1.2 \mathrm{~kg})$ was fractionated into six fractions A-F $(300,120,150,230,165$, 220 g) via silica gel column chromatography (CC) using acetone-petroleum ether (PE) gradient (5:95, 10:90, 20:80, 30:70, 40:60 and 50:50, v/v). Fr. C (150 g) was separated through MPLC on an MCI gel CHP 20P column and eluted with a gradient of $\mathrm{H}_{2} \mathrm{O}-\mathrm{MeOH}(50: 50,30: 70,20: 80$ and 0:100) to give four subfractions (Frs. C1-C4). Fr. C1 (29 g) was subjected to silica gel CC (EtOAc-PE, 10:90 to 30:70) to afford three subfractions (Frs. C1-1-C1-3). Compound 4 (1.9 g) was obtained by recrystallization in $\mathrm{MeOH}$ from Fr. C1-1 (12.5 g). Fr. C1-2 (7 g) was chromatographed over Sephadex LH-20 CC (MeOH-CHCl 3 , 50:50) and further purified by semi-preparative HPLC $\left(\mathrm{H}_{2} \mathrm{O}-\mathrm{MeCN}, 38: 62\right)$ to provide compound $2\left(6 \mathrm{mg}, t_{\mathrm{R}}=27.5 \mathrm{~min}\right)$. Fr. C2 $(35 \mathrm{~g})$ was separated into three subfractions (Frs. C2-1-C2-3) via silica gel CC with a gradient of EtOAc-PE (15:85 to 30:70). From Fr. C2-1 (1.5 g), compounds $1\left(30 \mathrm{mg}, t_{\mathrm{R}}=13.0 \mathrm{~min}\right)$ and $12\left(8 \mathrm{mg}, t_{\mathrm{R}}=39.5 \mathrm{~min}\right)$ was obtained by semi-preparative $\mathrm{HPLC}$ with $\mathrm{H}_{2} \mathrm{O}-\mathrm{MeCN}$ (42:58) as the mobile phase. Fr. C2-3 (12 g) was submitted on silica gel CC with a step gradient of acetone-PE (20:80 to 30:70) and further purified by semi-preparative $\mathrm{HPLC}\left(\mathrm{H}_{2} \mathrm{O}-\mathrm{MeOH}, 51: 49\right)$ to 
yield compounds $3\left(62 \mathrm{mg}, t_{\mathrm{R}}=23.5 \mathrm{~min}\right)$ and $\mathbf{1 0}(9 \mathrm{mg}$, $\left.t_{\mathrm{R}}=35.0 \mathrm{~min}\right)$. Fr. C4 (16.5 g) was separated on silica gel CC (EtOAc-PE, 15:85 to 30:70) to give three subfractions (Frs. C4-1-C4-3). Compounds $5\left(85 \mathrm{mg}, t_{\mathrm{R}}=25.0 \mathrm{~min}\right)$, $6\left(15 \mathrm{mg}, t_{\mathrm{R}}=21.5 \mathrm{~min}\right), 8\left(7 \mathrm{mg}, t_{\mathrm{R}}=14.0 \mathrm{~min}\right)$, and $11\left(88 \mathrm{mg}, t_{\mathrm{R}}=32.0 \mathrm{~min}\right)$ were provided from Fr. C4-2 $(1.3 \mathrm{~g})$ by semi-preparative HPLC $\left(\mathrm{H}_{2} \mathrm{O}-\mathrm{MeCN}, 42: 58\right)$. Fr. C4-3 (2.7 g) was subjected to Sephadex LH-20 CC $\left(\mathrm{MeOH}-\mathrm{CHCl}_{3}, 50: 50\right)$ and further purified by semi-preparative HPLC $\left(\mathrm{H}_{2} \mathrm{O}-\mathrm{MeCN}, 47: 53\right)$ to afford compounds 7 $\left(4 \mathrm{mg}, t_{\mathrm{R}}=19.0 \mathrm{~min}\right)$ and $9\left(4 \mathrm{mg}, t_{\mathrm{R}}=15.0 \mathrm{~min}\right)$.

\subsection{Spectroscopy Data of Compounds}

The ${ }^{1} \mathrm{H}$ NMR spectra of artemyrianins A-G (1-7) were recorded in $\mathrm{CDCl}_{3}$ at $600 \mathrm{MHz}$, and their ${ }^{13} \mathrm{C}$ NMR (DEPT) spectra were recorded in $\mathrm{CDCl}_{3}$ at $150 \mathrm{MHz}$.

\subsubsection{Artemyrianin A (1)}

Colorless, prismatic crystals $(\mathrm{MeOH}) ; \mathrm{mp} 95.8-97.5^{\circ} \mathrm{C}$; $[\alpha]_{\mathrm{D}}^{22}+45(c 0.13, \mathrm{MeOH}) ; \mathrm{UV}(\mathrm{MeOH}) \lambda_{\max }(\log \varepsilon) 206$ (3.69), 224 (3.73), 266 (3.49) nm; IR $\nu_{\max }$ 1771, 1671, 1606, 1454, $1132 \mathrm{~cm}^{-1}$; ${ }^{1} \mathrm{H}$ NMR and ${ }^{13} \mathrm{C}$ NMR (DEPT) data see Table 1; (+)-HRESIMS $\mathrm{m} / z 233.1518[\mathrm{M}+\mathrm{H}]^{+}$(calcd for $\mathrm{C}_{15} \mathrm{H}_{21} \mathrm{O}_{2}$, 233.1536).

\subsubsection{Artemyrianin B (2)}

White amorphous powder; $[\alpha]_{\mathrm{D}}^{22}-205(c 0.11, \mathrm{MeOH})$; $\mathrm{UV}(\mathrm{MeOH}) \lambda_{\max }(\log \varepsilon) 263(3.06) \mathrm{nm} ; \mathrm{ECD}(\mathrm{MeOH})$ $\lambda_{\max }(\Delta \varepsilon) 213(-0.14), 238(+3.00), 272(-20.81) \mathrm{nm}$; IR $(\mathrm{KBr}) \nu_{\max } 3435,1771,1716,1633,1291,1171,1085$, $1026 \mathrm{~cm}^{-1} ;{ }^{1} \mathrm{H}$ NMR and ${ }^{13} \mathrm{C}$ NMR (DEPT) data see Table 1; (-)-HRESIMS m/z $279.1242[\mathrm{M}-\mathrm{H}]^{-}$(calcd for $\left.\mathrm{C}_{15} \mathrm{H}_{19} \mathrm{O}_{5}, 279.1238\right)$.

\subsubsection{Artemyrianin C (3)}

White amorphous powder; $[\alpha]_{\mathrm{D}}^{24}-110(c 0.11, \mathrm{MeOH}) ; \mathrm{UV}$ $(\mathrm{MeOH}) \lambda_{\max }(\log \varepsilon) 204(4.08) \mathrm{nm} ; \mathrm{ECD}(\mathrm{MeOH}) \lambda_{\max }$ $(\Delta \varepsilon) 219(+2.17) \mathrm{nm}$; IR (KBr) $\nu_{\max } 3434,1735,1720$, $1629,1440,1376,1247,1148 \mathrm{~cm}^{-1} ;{ }^{1} \mathrm{H}$ NMR and ${ }^{13} \mathrm{C}$ NMR (DEPT) data see Table 1; (+)-HRESIMS $m / z$ 345.1675 $[\mathrm{M}+\mathrm{Na}]^{+}$(calcd for $\mathrm{C}_{18} \mathrm{H}_{26} \mathrm{O}_{5} \mathrm{Na}, 345.1672$ ).

\subsubsection{Artemyrianin D (4)}

White amorphous powder; $[\alpha]_{\mathrm{D}}^{24}-111(c 0.16, \mathrm{MeOH}) ; \mathrm{UV}$ $(\mathrm{MeOH}) \lambda_{\max }(\log \varepsilon) 206(3.82) \mathrm{nm} ; \mathrm{ECD}(\mathrm{MeOH}) \lambda_{\max }$ $(\Delta \varepsilon) 196(-5.96), 254(+0.56) \mathrm{nm}$; IR $(\mathrm{KBr}) \nu_{\max } 3501$,
3459, 1701, 1626, 1290, $1245 \mathrm{~cm}^{-1},{ }^{1} \mathrm{H}$ NMR and ${ }^{13} \mathrm{C}$ NMR (DEPT) data see Table 1; (+)-HRESIMS $\mathrm{m} / z 305.1725$ $[\mathrm{M}+\mathrm{Na}]^{+}$(calcd for $\mathrm{C}_{16} \mathrm{H}_{26} \mathrm{O}_{4} \mathrm{Na}, 305.1723$ ).

\subsubsection{Artemyrianin E (5)}

Yellowish oil; $[\alpha]_{\mathrm{D}}^{27}-185$ ( $c$ 0.22, $\left.\mathrm{MeOH}\right) ; \mathrm{UV}(\mathrm{MeOH}) \lambda_{\max }$ $(\log \varepsilon) 215$ (4.18), 267 (4.04), 290 (3.87) nm; ECD (MeCN) $\lambda_{\max }(\Delta \varepsilon) 201(+18.46), 224(-4.18), 241(-2.24), 262$ $(-5.89), 282(-3.15), 300(-5.71) \mathrm{nm}$; IR $\nu_{\max } 3384,1606$, $1503,1489,1444,1250,1190,1039,929,804 \mathrm{~cm}^{-1} ;{ }^{1} \mathrm{H}$ NMR and ${ }^{13} \mathrm{C}$ NMR (DEPT) data see Table 2; HREIMS $\mathrm{m} / \mathrm{z}$ $326.1148[\mathrm{M}]^{+}$(calcd for $\left.\mathrm{C}_{19} \mathrm{H}_{18} \mathrm{O}_{5}, 326.1154\right)$.

\subsubsection{Artemyrianin F (6)}

Yellowish oil; $[\alpha]_{\mathrm{D}}^{19}+152(c 0.15, \mathrm{MeOH})$; $\mathrm{UV}(\mathrm{MeCN}) \lambda_{\max }$ $(\log \varepsilon) 262$ (3.03), $290(2.95) \mathrm{nm}$; ECD $(\mathrm{MeCN}) \lambda_{\max }(\Delta \varepsilon)$ 200 (-40.56), 215 (+15.69), 240 (+2.92), $297(+5.89) \mathrm{nm}$; IR $(\mathrm{KBr}) \nu_{\max } 3404,1607,1503,1489,1442,1245,1189$, 1040, 928, 869, $812 \mathrm{~cm}^{-1} ;{ }^{1} \mathrm{H}$ NMR and ${ }^{13} \mathrm{C}$ NMR (DEPT) data see Table 2; HREIMS $\mathrm{m} / \mathrm{z} 326.1152[\mathrm{M}]^{+}$(calcd for $\left.\mathrm{C}_{19} \mathrm{H}_{18} \mathrm{O}_{5}, 326.1154\right)$.

\subsubsection{Artemyrianin G (7)}

White amorphous powder; $[\alpha]_{\mathrm{D}}^{26}-18(c 0.12, \mathrm{MeOH})$; $\mathrm{UV}(\mathrm{MeOH}) \lambda_{\max }(\log \varepsilon) 235$ (3.63), 287 (3.59) nm; ECD $(\mathrm{MeCN}) \lambda_{\max }(\Delta \varepsilon) 206(+5.76), 248(+0.20), 282(+0.29)$ $\mathrm{nm}$; IR $\nu_{\max } 3406,1608,1503,1490,1443,1247,1189$, 1099, 1039, 927, $811 \mathrm{~cm}^{-1}$; ${ }^{1} \mathrm{H}$ NMR and ${ }^{13} \mathrm{C}$ NMR (DEPT) data see Table 2; HREIMS $\mathrm{m} / \mathrm{z} 342.1104 \mathrm{[M]}^{+}$(calcd for $\left.\mathrm{C}_{19} \mathrm{H}_{18} \mathrm{O}_{6}, 342.1103\right)$.

\subsection{X-ray Crystallographic Analysis of Artemyrianin $A$ (1)}

Single crystals of compound 1 were obtained from $\mathrm{MeOH}$. $\mathrm{X}$-ray crystallographic data were collected on a Bruker D8 Quest apparatus employing graphite-monochromated $\mathrm{Cu}$ $K \alpha$ radiation at 100.(2) K. Cell refinement and data reduction were carried out by the aid of Bruker SAINT. The structure was solved by direct methods with SHELXS-97. All non-hydrogen atoms were refined anisotropically by means of the least-squares method, and all hydrogen atoms were positioned using difference Fourier overlapping calculation and geometric calculations. Flack parameter $=0.18(14)$. The crystallographic data for 1 have been deposited at the Cambridge Crystallographic Data Centre (CCDC) as Supplementary Publication No. CCDC 1985641. Copy of the data can be obtained free of charge 
Table $1{ }^{1} \mathrm{H}$ NMR and ${ }^{13} \mathrm{C}$ NMR (DEPT) data for compounds $\mathbf{1 - 4}(\delta$ in ppm, $J$ in $\mathrm{Hz})$

\begin{tabular}{|c|c|c|c|c|c|c|c|c|}
\hline \multirow[t]{2}{*}{ No. } & \multicolumn{2}{|l|}{1} & \multicolumn{2}{|l|}{2} & \multicolumn{2}{|l|}{3} & \multicolumn{2}{|l|}{4} \\
\hline & $\delta_{\mathrm{C}}$ & $\delta_{\mathrm{H}}$ & $\delta_{\mathrm{C}}$ & $\delta_{\mathrm{H}}$ & $\delta_{\mathrm{C}}$ & $\delta_{\mathrm{H}}$ & $\delta_{\mathrm{C}}$ & $\delta_{\mathrm{H}}$ \\
\hline \multirow[t]{2}{*}{1} & 203.9, C & - & $87.2, \mathrm{C}$ & - & 46.9, $\mathrm{CH}$ & $3.17, \mathrm{~m}$ & $41.3, \mathrm{CH}_{2}$ & Ha: $1.45, \mathrm{ol}^{a}$ \\
\hline & - & - & - & - & - & - & - & $\begin{array}{l}\text { Hb: } 1.08, \operatorname{td}(12.6 \text {, } \\
5.0)\end{array}$ \\
\hline \multirow[t]{2}{*}{2} & $61.2, \mathrm{CH}$ & $3.68, \mathrm{~d}(7.4)$ & 28.9, $\mathrm{CH}_{2}$ & $\begin{array}{l}\text { Ha: } 2.24 \text {, ddd (14.9, } \\
9.8,5.2)\end{array}$ & 27.0, $\mathrm{CH}_{2}$ & Ha: $1.96, \mathrm{ol}^{a}$ & 19.7, $\mathrm{CH}_{2}$ & $1.57, \mathrm{~m}$ \\
\hline & - & - & - & $\mathrm{Hb}: 1.94, \mathrm{~m}$ & - & $\mathrm{Hb}: 1.76, \mathrm{ol}^{a}$ & - & - \\
\hline \multirow[t]{2}{*}{3} & $145.5, \mathrm{C}$ & - & $38.1, \mathrm{CH}_{2}$ & $\begin{array}{l}\text { Ha: } 2.70 \text {, ddd (18.2, } \\
\quad 9.8,5.6)\end{array}$ & $40.3, \mathrm{CH}_{2}$ & $1.76, \mathrm{~m}$ & 43.6, $\mathrm{CH}_{2}$ & Ha: $1.83, \mathrm{~m}$ \\
\hline & - & - & - & $\begin{array}{l}\text { Hb: } 2.53 \text {, ddd (18.2, } \\
9.7,5.2)\end{array}$ & - & - & - & $\mathrm{Hb}: 1.37, \mathrm{~m}$ \\
\hline 4 & 148.7, CH & $7.00, \mathrm{~d}(2.2)$ & 207.8, C & - & $81.8, \mathrm{C}$ & - & $72.4, \mathrm{C}$ & - \\
\hline 5 & $57.1, \mathrm{CH}$ & $2.75, \mathrm{q}(2.2)$ & 142.6, CH & $6.19, \mathrm{~d}(9.5)$ & $54.1, \mathrm{CH}$ & $\begin{array}{l}2.03 \text {, ddd (12.1, 9.5, } \\
2.5)\end{array}$ & $56.0, \mathrm{CH}$ & $1.36, \mathrm{ol}^{a}$ \\
\hline \multirow[t]{2}{*}{6} & $38.2, \mathrm{C}$ & - & $119.5, \mathrm{CH}$ & $6.59, \mathrm{~d}(9.5)$ & $26.5, \mathrm{CH}_{2}$ & Ha: $1.66, \mathrm{~m}$ & $20.1, \mathrm{CH}_{2}$ & $1.69, \mathrm{~m}$ \\
\hline & - & - & - & - & - & $\mathrm{Hb}: 1.44, \mathrm{~m}$ & - & - \\
\hline \multirow[t]{2}{*}{7} & 43.2, $\mathrm{CH}_{2}$ & Ha: $1.54, \mathrm{ol}^{a}$ & 155.7, C & - & $44.3, \mathrm{CH}$ & $2.95, \mathrm{~m}$ & 45.7, $\mathrm{CH}$ & $2.86, \mathrm{~m}$ \\
\hline & - & $\mathrm{Hb}: 1.43, \mathrm{~m}$ & - & - & - & - & - & - \\
\hline \multirow[t]{2}{*}{8} & 21.6, $\mathrm{CH}_{2}$ & Ha: $1.55, \mathrm{ol}^{a}$ & $106.4, \mathrm{C}$ & - & $70.7, \mathrm{CH}$ & $5.09, \mathrm{dt}(6.0,2.8)$ & $68.0, \mathrm{CH}$ & $4.06, \mathrm{~m}$ \\
\hline & - & $\mathrm{Hb}: 1.35, \mathrm{~m}$ & - & - & - & - & - & - \\
\hline \multirow[t]{2}{*}{9} & $33.8, \mathrm{CH}_{2}$ & $1.65, \mathrm{~m}$ & $38.7, \mathrm{CH}_{2}$ & $\begin{array}{l}\text { Ha: } 2.60, \text { dd }(13.2, \\
\quad 10.6)\end{array}$ & $40.7, \mathrm{CH}_{2}$ & $\begin{array}{l}\text { Ha: } 2.72, \text { dd (13.9, } \\
\quad 6.0)\end{array}$ & $49.9, \mathrm{CH}_{2}$ & Ha: $1.81, \mathrm{ol}^{a}$ \\
\hline & - & - & - & $\mathrm{Hb}: 1.63, \mathrm{~m}$ & - & $\begin{array}{l}\text { Hb: } 2.31, \mathrm{dd}(13.9, \\
2.8)\end{array}$ & - & $\mathrm{Hb}: 1.46, \mathrm{ol}^{a}$ \\
\hline 10 & $35.4, \mathrm{C}$ & - & 41.7, $\mathrm{CH}$ & $2.42, \mathrm{dp}(10.6,7.0)$ & $144.9, \mathrm{C}$ & - & $34.8, \mathrm{C}$ & - \\
\hline 11 & $65.7, \mathrm{CH}$ & $2.99, \mathrm{dt}(7.4,2.2)$ & 117.2, C & - & $142.9, \mathrm{C}$ & - & $142.0, \mathrm{C}$ & - \\
\hline 12 & $26.5, \mathrm{CH}_{3}$ & $1.01, \mathrm{~s}$ & 172.0, C & - & 167.3, C & - & $167.7, \mathrm{C}$ & - \\
\hline \multirow[t]{2}{*}{13} & $30.5, \mathrm{CH}_{3}$ & $1.16, \mathrm{~s}$ & $8.2, \mathrm{CH}_{3}$ & $1.89, \mathrm{~s}$ & $125.8, \mathrm{CH}_{2}$ & Ha: $6.26, \mathrm{~s}$ & $126.5, \mathrm{CH}_{2}$ & Ha: $6.39, \mathrm{~d}(1.2)$ \\
\hline & - & - & - & - & - & $\mathrm{Hb}: 5.53, \mathrm{~s}$ & - & $\mathrm{Hb}: 5.73, \mathrm{t}(1.2)$ \\
\hline \multirow[t]{2}{*}{14} & $27.5, \mathrm{CH}_{3}$ & $1.28, \mathrm{~s}$ & $15.5, \mathrm{CH}_{3}$ & $1.01, \mathrm{~d}(7.0)$ & 114.0, $\mathrm{CH}_{2}$ & Ha: $4.91, \mathrm{~s}$ & $21.1, \mathrm{CH}_{3}$ & $1.12, \mathrm{~s}$ \\
\hline & - & - & - & - & - & $\mathrm{Hb}: 4.78, \mathrm{~s}$ & - & - \\
\hline 15 & $189.9, \mathrm{CH}$ & $9.54, \mathrm{~s}$ & $30.0, \mathrm{CH}_{3}$ & $2.15, \mathrm{~s}$ & $24.5, \mathrm{CH}_{3}$ & $1.23, \mathrm{~s}$ & $23.0, \mathrm{CH}_{3}$ & $1.20, \mathrm{~s}$ \\
\hline $1^{\prime}$ & - & - & - & - & $170.6, \mathrm{C}$ & - & $52.2, \mathrm{CH}_{3}$ & $3.78, \mathrm{~s}$ \\
\hline $2^{\prime}$ & - & - & - & - & $21.3, \mathrm{CH}_{3}$ & $1.98, \mathrm{~s}$ & - & - \\
\hline $1^{\prime \prime}$ & - & - & - & - & $52.2, \mathrm{CH}_{3}$ & $3.76, \mathrm{~s}$ & - & - \\
\hline
\end{tabular}

a "ol" is used to indicate overlapped signals, for which the coupling constants could not be read

from CCDC, 12 Union Road, Cambridge CB2 1EZ, UK [fax: +44 (0) 1223 336033; e-mail: deposit@ccdc.cam. ac.uk].

\subsubsection{Crystal Data for 1}

$\mathrm{C}_{15} \mathrm{H}_{20} \mathrm{O}_{2}, M=232.31, a=6.7424(3) \AA, b=6.9858(3) \AA$, $c=7.7309(3) \AA, \alpha=105.3440(10)^{\circ}, \beta=101.9110(10)^{\circ}$, $\gamma=106.6430(10)^{\circ}, V=320.37(2) \AA^{3}, T=100$.(2) K, space group $P 1, Z=1, \mu(\mathrm{Cu} K \alpha)=0.615 \mathrm{~mm}^{-1}, 4616$ reflections measured, 2090 independent reflections $\left(R_{\text {int }}=0.0519\right)$.
The final $R_{1}$ values were $0.0484[I>2 \sigma(I)]$. The final $w R\left(F^{2}\right)$ values were $0.1244[I>2 \sigma(I)]$. The final $R_{1}$ values were 0.0485 (all data). The final $w R\left(F^{2}\right)$ values were 0.1245 (all data). The goodness of fit on $F^{2}$ was 1.040 . Flack parameter $=0.18(14)$.

\subsection{Computational Details}

The ECD calculations for compounds 2-7 were achieved by Gaussian 09 program. The configurations of compounds 2-4 and 7 were initially established on the basis of their 
258

S. Tang et al.

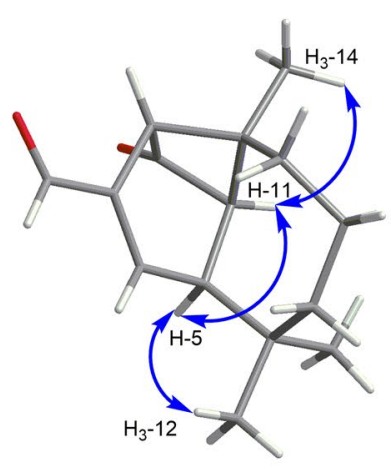

1

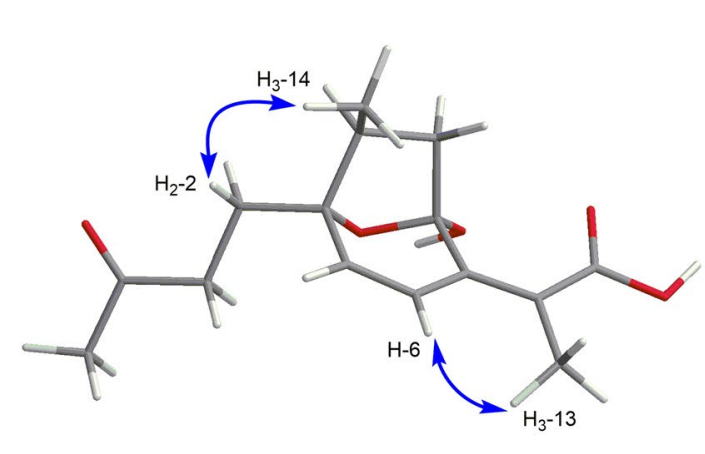

2

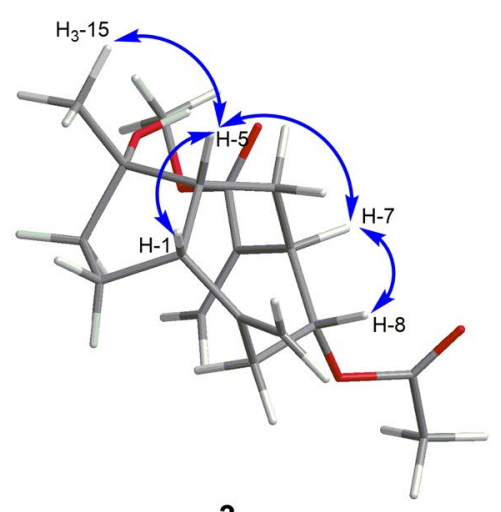

3
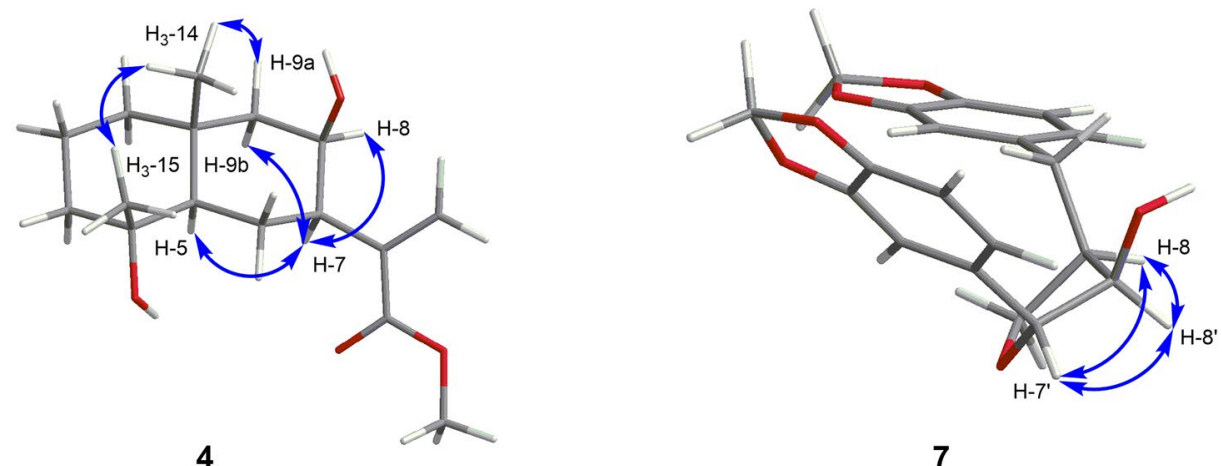

7

Fig. 4 Key ROESY correlations of compounds $\mathbf{1 - 4}$ and $\mathbf{7}$
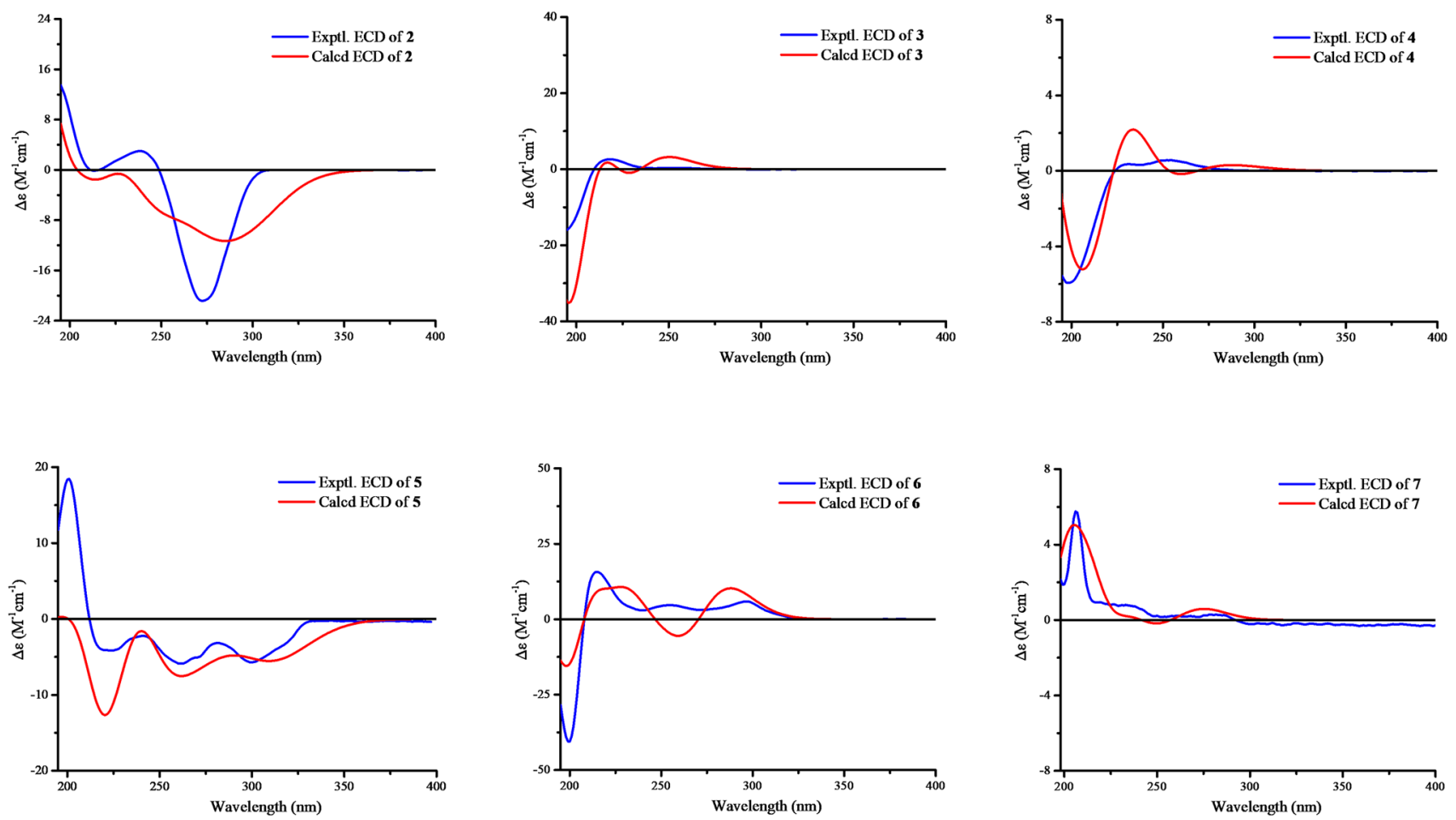

Fig. 5 The experimental and calculated ECD spectra of compounds 2-7

Springer 
Table $2{ }^{1} \mathrm{H}$ NMR and ${ }^{13} \mathrm{C}$ NMR (DEPT) data for compounds 5-7 ( $\delta$ in ppm, $J$ in $\left.\mathrm{Hz}\right)$

\begin{tabular}{|c|c|c|c|c|c|c|}
\hline \multirow[t]{2}{*}{ No. } & \multicolumn{2}{|l|}{5} & \multicolumn{2}{|l|}{6} & \multicolumn{2}{|l|}{7} \\
\hline & $\delta_{\mathrm{C}}$ & $\delta_{\mathrm{H}}$ & $\delta_{\mathrm{C}}$ & $\delta_{\mathrm{H}}$ & $\delta_{\mathrm{C}}$ & $\delta_{\mathrm{H}}$ \\
\hline 1 & 133.5, C & - & $133.4, \mathrm{C}$ & - & 134.1, C & - \\
\hline 2 & 109.6, CH & $6.67, \mathrm{~d}(1.8)$ & $109.8, \mathrm{CH}$ & $6.62, \mathrm{ol}^{a}$ & $108.5, \mathrm{CH}$ & $6.69, \mathrm{~d}(1.6)$ \\
\hline 3 & $145.9, \mathrm{C}$ & - & $147.6, \mathrm{C}$ & - & $148.0, \mathrm{C}$ & - \\
\hline 4 & 147.7, C & - & 146.6, C & - & 146.1, C & - \\
\hline 5 & $108.2, \mathrm{CH}$ & $6.70, \mathrm{ol}^{a}$ & $108.3, \mathrm{CH}$ & $6.70, \mathrm{~d}(7.9)$ & $109.2, \mathrm{CH}$ & $6.72, \mathrm{~d}(7.9)$ \\
\hline 6 & $122.2, \mathrm{CH}$ & $6.61, \mathrm{dd}(7.9,1.8)$ & $122.2, \mathrm{CH}$ & $6.59, \mathrm{ol}^{a}$ & $121.5, \mathrm{CH}$ & 6.64, dd $(7.9,1.6)$ \\
\hline 7 & $\begin{array}{l}37.8, \mathrm{CH}_{2} \\
-\end{array}$ & $\begin{array}{l}\text { Ha: } 2.72, \text { dd }(13.3,6.6) \\
\text { Hb: } 2.63 \text {, dd }(13.3,7.3)\end{array}$ & $\begin{array}{l}38.1, \mathrm{CH}_{2} \\
-\end{array}$ & $\begin{array}{l}\text { Ha: } 2.70, \text { dd }(13.7,6.3) \\
\text { Hb: } 2.55 \text {, dd }(13.7,7.8)\end{array}$ & $\begin{array}{l}31.6, \mathrm{CH}_{2} \\
-\end{array}$ & $\begin{array}{l}\text { Ha: } 2.84 \text {, dd }(13.9,7.9) \\
\text { Hb: } 2.65 \text {, dd }(13.9,7.7)\end{array}$ \\
\hline 8 & 47.7, $\mathrm{CH}$ & $2.59, \mathrm{~m}$ & $42.6, \mathrm{CH}$ & $3.13, \mathrm{~m}$ & $44.6, \mathrm{CH}$ & $2.47, \mathrm{~m}$ \\
\hline 9 & $\begin{array}{l}65.3, \mathrm{CH}_{2} \\
-\end{array}$ & $\begin{array}{l}\text { Ha: } 3.63 \text {, dd }(10.6,5.0) \\
\text { Hb: } 3.52 \text {, dd }(10.6,7.0)\end{array}$ & $\begin{array}{l}66.0, \mathrm{CH}_{2} \\
-\end{array}$ & $\begin{array}{l}\text { Ha: } 3.62 \text {, dd }(10.6,5.4) \\
\text { Hb: } 3.51, \text { dd }(10.6,7.4)\end{array}$ & $\begin{array}{l}\text { 72.1, } \mathrm{CH}_{2} \\
-\end{array}$ & $\begin{array}{l}\text { Ha: } 4.17, \mathrm{t}(8.2) \\
\text { Hb: } 3.81, \mathrm{dd}(10.2,8.2)\end{array}$ \\
\hline $1^{\prime}$ & 131.7, C & - & $131.3, \mathrm{C}$ & - & $135.2, \mathrm{C}$ & - \\
\hline $2^{\prime}$ & 105.6, CH & $6.87, \mathrm{~d}(1.6)$ & $109.0, \mathrm{CH}$ & $6.60, \mathrm{ol}^{a}$ & $106.1, \mathrm{CH}$ & 6.79, br s \\
\hline $3^{\prime}$ & $147.2, \mathrm{C}$ & - & $146.1, \mathrm{C}$ & - & 147.0, C & - \\
\hline $4^{\prime}$ & 148.1, C & - & 147.7, C & - & 148.0, C & - \\
\hline $5^{\prime}$ & $108.4, \mathrm{CH}$ & $6.72, \mathrm{ol}^{a}$ & $108.3, \mathrm{CH}$ & $6.72, \mathrm{~d}(7.7)$ & $108.4, \mathrm{CH}$ & $6.76, \mathrm{ol}^{a}$ \\
\hline $6^{\prime}$ & $120.9, \mathrm{CH}$ & $6.74, \mathrm{dd}(8.0,1.6)$ & $122.3, \mathrm{CH}$ & $6.59, \mathrm{ol}^{a}$ & $118.7, \mathrm{CH}$ & $6.76, \mathrm{ol}^{a}$ \\
\hline $7^{\prime}$ & $132.0, \mathrm{CH}$ & $6.32, \mathrm{~d}(15.7)$ & $132.2, \mathrm{CH}$ & $6.52, \mathrm{~d}(11.6)$ & $88.6, \mathrm{CH}$ & $4.87, \mathrm{~d}(2.0)$ \\
\hline $8^{\prime}$ & $129.0, \mathrm{CH}$ & 5.88, dd $(15.7,8.0)$ & $132.2, \mathrm{CH}$ & $5.37, \mathrm{dd}(11.6,10.5)$ & $79.6, \mathrm{CH}$ & $4.05, \mathrm{dd}(5.1,2.0)$ \\
\hline $\mathrm{OCH}_{2} \mathrm{O}$ & $\begin{array}{l}101.2, \mathrm{CH}_{2} \\
100.9, \mathrm{CH}_{2}\end{array}$ & $\begin{array}{l}5.92, \mathrm{~s} \\
5.90, \mathrm{~s}\end{array}$ & $\begin{array}{l}101.2, \mathrm{CH}_{2} \\
101.0, \mathrm{CH}_{2}\end{array}$ & $\begin{array}{l}5.94, \mathrm{~s} \\
5.91, \mathrm{~s}\end{array}$ & $\begin{array}{l}101.2, \mathrm{CH}_{2} \\
101.1, \mathrm{CH}_{2}\end{array}$ & $\begin{array}{l}5.94, \mathrm{~s} \\
5.92, \mathrm{~s}\end{array}$ \\
\hline
\end{tabular}

a"ol" is used to indicate overlapped signals, for which the coupling constants could not be read

ROESY data, and further optimized by means of the DFT calculation at b3lyp/6-31G(d,p) level in the gas phase. The imaginary frequencies were excluded by the aid of frequency calculations at the same level. Taking the solvent effects into consideration, ECD calculations were carried out using the TDDFT methodology at b3lyp/6-311+g(d,p) level. The ECD curves were plotted by the Origin Pro 9 program (OriginLab Corporation, Northampton, USA).

\subsection{Cytotoxicity Assay}

MTT assays were conducted to evaluate the cytotoxic activity of the isolates on HepG2 cells [23]. HepG2 cells were seeded onto 96-well plates at a density of $1 \times 10^{4}$ cells per well. Following $24 \mathrm{~h}$ incubation at $37{ }^{\circ} \mathrm{C}$ with $5 \% \mathrm{CO}_{2}$, cells were treated with $100 \mu \mathrm{L}$ of culture medium containing tested samples at gradient concentrations for $48 \mathrm{~h}$. Next, the medium was removed and replaced by $100 \mu \mathrm{L}$ MTT solution $(1 \mathrm{mg} / \mathrm{mL})$, and the plates were further incubated in dark for four h. After removing the medium, $100 \mu \mathrm{L}$ DMSO was added into each well to dissolve the MTT formazan salt. Then the plates were measured at $490 \mathrm{~nm}$ on a microplate reader (Bio-Rad, USA). The cytotoxicity of compounds was expressed as $\mathrm{IC}_{50}$ values which calculated by GraphPad prism 5 (GraphPad Software, San Diego, California, USA). The HepG2 cells (Jining Biotechnology Co., Ltd.,

Table 3 Cytotoxic activity of compounds against HepG2 cells

\begin{tabular}{lclc}
\hline Compound & $\mathrm{IC}_{50} \pm \mathrm{SD}(\mu \mathrm{M})^{a}$ & Compound & $\mathrm{IC}_{50} \pm \mathrm{SD}(\mu \mathrm{M})^{a}$ \\
\hline $\mathbf{1}$ & $117.5 \pm 3.8$ & $\mathbf{8}$ & $76.8 \pm 6.5$ \\
$\mathbf{2}$ & $119.2 \pm 8.3$ & $\mathbf{9}$ & $126.4 \pm 1.5$ \\
$\mathbf{3}$ & $145.2 \pm 5.3$ & $\mathbf{1 0}$ & $134.8 \pm 8.0$ \\
$\mathbf{4}$ & $55.4 \pm 3.8$ & $\mathbf{1 1}$ & $133.2 \pm 12.6$ \\
$\mathbf{5}$ & $33.3 \pm 0.6$ & $\mathbf{1 2}$ & $47.1 \pm 6.1$ \\
$\mathbf{6}$ & $66.4 \pm 0.7$ & Sorafenib & $9.2 \pm 2.7$ \\
$\mathbf{7}$ & $96.9 \pm 8.1$ & & \\
\hline
\end{tabular}

${ }^{a}$ Data were expressed as means $\pm \mathrm{SD}(n=3)$ from three independent experiments 
Shanghai, China) were maintained at $37^{\circ} \mathrm{C}$ with $5 \% \mathrm{CO}_{2}$ and grown in Dulbecco's Modified Eagle Medium (DMEM) (Gibco, Thermo Fisher Scientific Co., Ltd., Suzhou, China) supplemented with $10 \%$ fetal bovine serum (FBS) (Gibco, Life Technologies, NY, USA) (Table 3).

Acknowledgements This work was financially supported by the Yunnan Wanren Project (YNWR-KJLJ-2019-002), the Program of Yunling Scholarship, the Reserve Talents of Young and Middle-aged Academic and Technical Leaders in Yunnan Province, and the Youth Innovation Promotion Association, CAS (2013252).

\section{Compliance with Ethical Standards}

Conflict of interest All authors declare no conflict of interest.

Open Access This article is licensed under a Creative Commons Attribution 4.0 International License, which permits use, sharing, adaptation, distribution and reproduction in any medium or format, as long as you give appropriate credit to the original author(s) and the source, provide a link to the Creative Commons licence, and indicate if changes were made. The images or other third party material in this article are included in the article's Creative Commons licence, unless indicated otherwise in a credit line to the material. If material is not included in the article's Creative Commons licence and your intended use is not permitted by statutory regulation or exceeds the permitted use, you will need to obtain permission directly from the copyright holder. To view a copy of this licence, visit http://creativecommons.org/licenses/by/4.0/.

\section{References}

1. F. Bray, J. Ferlay, I. Soerjomataram, R.L. Siegel, L.A. Torre, A. Jemal, CA Cancer J. Clin. 68, 394-424 (2018)

2. Q.Z. Dai, C.L. Zhang, Z.G. Yuan, Q.S. Sun, Y.Y. Jiang, Expert Opin. Drug Discov. 15, 243-258 (2020)
3. A. Ghantous, H. Gali-Muhtasib, H. Vuorela, N.A. Saliba, N. Darwiche, Drug Discov. Today 15, 668-678 (2010)

4. S.H. Lone, K.A. Bhat, M.A. Khuroo, Chem. Biol. Interact. 240, 180-198 (2015)

5. H.F. Wong, G.D. Brown, J. Nat. Prod. 65, 481-486 (2002)

6. H.F. Wong, G.D. Brown, Phytochemistry 59, 529-536 (2002)

7. Q.J. Li, W.P. Chen, J.H. Fan, Q. Zhao, X.H. Li, Q. Yang, C.Y. Liu, Chin. J. Mod. Appl. Pharm. 31, 706-710 (2014)

8. K. Zan, X.Q. Chen, M.B. Zhao, P.F. Tu, China J. Chin. Mater. Med. 41, 2833-2837 (2016)

9. K. Zan, X.Q. Chen, P.F. Tu, China J. Chin. Mater. Med. 43, 2295$2299(2018)$

10. G.C. Shah, C.S. Mathela, J. Essent. Oil Res. 18, 633-634 (2006)

11. G.D. Bagchi, F. Haider, N. Kumar, S.C. Singh, A.A. Naqvi, J. Essent. Oil Res. 21, 43-45 (2009)

12. X.Y. Dai, X. Li, X.R. Dong, B.L. Zhou, M. Xie, J. Anhui, Agric. Sci. 40, 11562-11564, 11597 (2012)

13. Y. Uchio, Tetrahedron 34, 2893-2899 (1978)

14. L.Y. Nie, J.J. Qin, Y. Huang, L. Yan, Y.B. Liu, Y.X. Pan, H.Z. Jin, W.D. Zhang, J. Nat. Prod. 73, 1117-1120 (2010)

15. L. Cardona, R.A. Aleman, B. Garcia, J.R. Pedro, Phytochemistry 31, 3630-3632 (1992)

16. C. Song, Y.Q. Li, Y.M. Yan, M. Hu, Q.Z. Zhang, Chem. Nat. Compd. 50, 414-416 (2014)

17. Q.M. Xu, Q. Li, Y.L. Liu, Y.L. Feng, S.L. Yang, X.R. Li, Chem. Nat. Compd. 46, 366-369 (2010)

18. G. Zhang, S. Shimokawa, M. Mochizuki, T. Kumamoto, W. Nakanishi, T. Watanabe, T. Ishikawa, K. Matsumoto, K. Tashima, S. Horie, Y. Higuchi, O.P. Dominguez, J. Nat. Prod. 71, $1167-$ $1172(2008)$

19. B. Raffaelli, K. Wähälä, T. Hase, Org. Biomol. Chem. 4, 331-341 (2006)

20. P. Panichayupakaranant, H. Noguchi, W. De-Eknamkul, U. Sankawa, Phytochemistry 40, 1141-1143 (1995)

21. J.H. Kwak, W.Y. Jang, O.P. Zee, K.R. Lee, Planta Med. 63, 474 476 (1997)

22. M. Talbi, B. Saadali, D. Boriky, L. Bennani, M. Elkouali, T. Ainane, J. Asian Nat. Prod. Res. 18, 724-729 (2016)

23. Y. Li, X.Y. Cheng, C.L. Chen, H.J. Wu, H. Zhao, W. Liu, Z. Xiang, Q. Wang, Pathol. Res. Pract. 216, 152701 (2020)

\section{Affiliations}

\section{Shuang Tang ${ }^{1,2} \cdot$ Yun-Bao Ma ${ }^{1} \cdot$ Chang-An Geng ${ }^{1} \cdot$ Cheng Shen ${ }^{1,2} \cdot$ Tian-Ze Li $^{1} \cdot$ Xue-Mei Zhang ${ }^{1} \cdot$ Li-Hua Su $^{1,2}$. Zhen $\mathrm{Gao}^{1,2}$. Jing Hu${ }^{1} \cdot$ Ji-Jun Chen ${ }^{1,2}$ (1)}

1 State Key Laboratory of Phytochemistry and Plant Resources in West China, Yunnan Key Laboratory of Natural Medicinal Chemistry, Kunming Institute of Botany, Chinese Academy of Sciences, Kunming 650201, People's Republic of China
2 University of Chinese Academy of Sciences, Beijing 100049, People's Republic of China 